\title{
Encephalitis in cat scratch disease with persistent dementia
}

\author{
A Revol, A Vighetto, A Jouvet, G Aimard, M Trillet
}

\begin{abstract}
Encephalitis in cat scratch disease is uncommon and usually reversible. The patient with cognitive impairment and severe memory disorder did not improve after a 30 month follow up. MRI revealed disseminated lesions in the white matter of the cerebral hemispheres.
\end{abstract}

Cat scratch disease (CSD) or benign inoculation lymphoreticulosis was first recognised in $1932^{1}$ and described in France in $1950 .^{23}$ The disease is uncommon and is characterised by subacute and often suppurating lymphadenitis, occurring a few days after a cat scratch or bite. Incidence of neurological complications is low, ranging from $1-3 \% .^{45}$ About 60 such cases have been documented, mainly presenting as acute encephalitis. ${ }^{56}$ The benign course of encephalitis has been emphasised, but we present an MRI documented case characterised by severe neurobehavioural results.

\section{Case report}

A 47 year old engine driver was admitted to hospital in January 1988 for mental confusion and headache of recent onset. On admission, he presented a grand mal seizure with post-ictal coma. Examination noted pyramidal syndrome with bilateral Babinski's sign and intermittent decerebrate posturing but no meningism. His temperature was $39^{\circ} \mathrm{C}$. An inflamed right epitrochlear lymph node and small ipsilateral axillary and cervical nodes were found. These nodes had appeared one month earlier with weakness, three weeks after the patient had had his right hand bitten by a kitten. His white cell count was $15 \times 10^{9} / 1$ with $14 \times 10^{9} / 1$ polymorphonuclear leucocytes and 450 lymphocytes. His cerebrospinal fluid (CSF) was clear, with a normal pressure; protein content was $0.53 \mathrm{~g} / \mathrm{l}$, without cells, and normal glucose concentration. Initial treatment consisted of penicillin, tetracyclin, sulfamethoxazol-trimethoprim, and acyclovir.

He regained consciousness four days later and remained confused and agitated for a few more days. Since then, neurological examination has been normal, apart from a severe intellectual deterioration with apathy, lack of initiative, and memory defect which lasted over the 30 months of follow up. He never recognised hospital and medical staff despite frequent outpatient visits. Eventually he could not live unassisted by his wife and did not resume his work nor his hobbies as a dog trainer. His oro-alimentary and sexual drives, however, remained normal.
Initial EEG demonstrated non-specific bilateral slowing, a subsequent one being normal. CT scan and arteriography were normal. MRI study performed eight months after the onset detected bilateral small foci of increased signal in the periventricular white matter (figure) on T2 weighted sequences. Skin test with tuberculin was positive. Intradermal reaction with cat scratch disease antigen (HangerRose test) performed 18 months after onset was positive with a $10 \mathrm{~mm}^{2}$ area of induration and a surrounding $25 \mathrm{~mm}^{2}$ erythematous area.

\section{INITIAL PSYCHOMETRIC EVALUATION AND} EVOLUTION

The patient was disoriented for time and place. He remembered with difficulty his job and his children's names and could not recall his address or old and recent political events. He was dysphoric and had no confabulation; his verbal span was 5 . On the Wechsler Bellevue test in February 1988 his global IQ was 85 (verbal IQ 85, performance IQ 89), and the deterioration quotient was $28 \%$. A subsequent evaluation in June 1989 found similar low values. Mini Mental State score remained between 15 and 20 (out of 30) without significant improvement over the 30 months of follow up. Spatial organisation was deficient, as shown in the Hooper visual organisation test (14/30) and in the Trail-making B memory tests, with Signoret. Whiteley's battery ${ }^{7}$ with a modified scale (unpublished), confirmed global deficit. Verbal and visual memory were tested

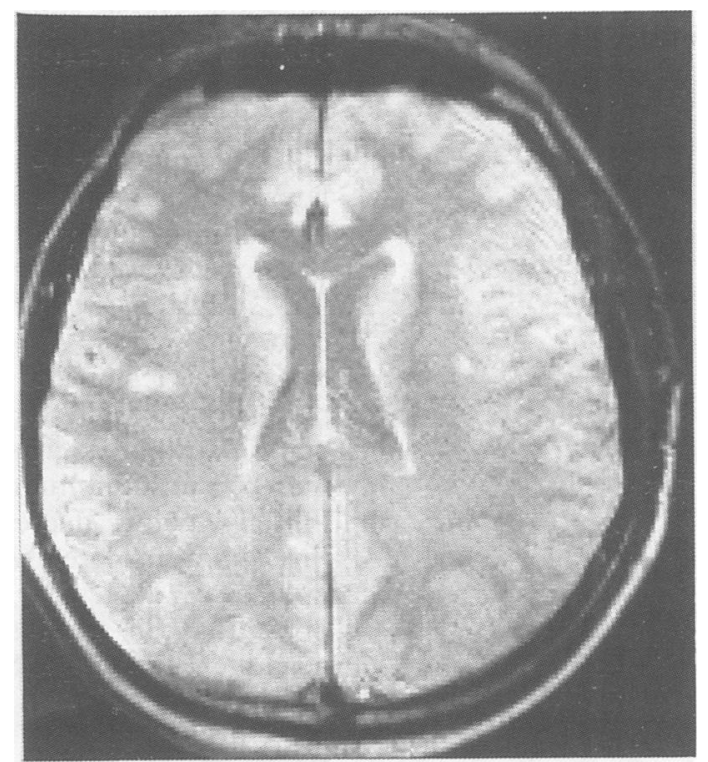

Figure Transverse MRI slice with $T 2$ sequence $(T R=$ $1800 \mathrm{msec} ; \mathrm{TE}=60 \mathrm{msec}$ ) showing bilateral hyperintense foci. 


\begin{tabular}{|c|c|c|c|c|}
\hline & \multicolumn{4}{|c|}{ Date of investigation } \\
\hline & 25 January 1988 & 27 January 1988 & 9 February 1988 & 21 April 1989 \\
\hline $\begin{array}{l}\text { CSF results } \\
\text { White cells }\left(\times 10^{6} / 1\right) \\
\text { Polymorphonuclears }(\%) \\
\text { Lymphocytes }(\%) \\
\text { Monocytes }(\%) \\
\text { Red cells }\left(\mathrm{mm}^{3}\right) \\
\text { Protein }(\mathrm{g} / \mathrm{l})\end{array}$ & $\begin{array}{l}<2 \\
- \\
- \\
<10 \\
0 \cdot 50\end{array}$ & $\begin{array}{l}40 \\
93 \\
5 \\
2 \\
5040 \\
0 \cdot 71\end{array}$ & $\begin{array}{l}<2 \\
67 \\
28 \\
5 \\
1500 \\
1 \cdot 20\end{array}$ & $\begin{array}{l}<2 \\
2 \\
84 \\
14 \\
22 \\
0 \cdot 38\end{array}$ \\
\hline $\begin{array}{l}\text { Antibodies in serum } \\
\text { Chlamydia psittaci }(\mathrm{lgG} / \mathrm{lgM})^{\star} \\
\text { Chlamydia trachomatis }(\operatorname{lgG} / \mathrm{lgM})^{\star} \\
\text { Toxoplasmosis } \\
\operatorname{lgG}(\mathrm{U} / \mathrm{ml})^{\star} \\
\text { Elisa }(\mathrm{U} / \mathrm{ml}) \\
\operatorname{lgM}\end{array}$ & $\begin{array}{l}256 / 0 \\
128 / 0 \\
80 \\
-\end{array}$ & $\begin{array}{l}128 / 0 \\
64 / 0 \\
8 \\
0\end{array}$ & $\begin{array}{l}64 / 0 \\
64 / 0 \\
8 \\
0 \\
0\end{array}$ & $\begin{array}{l}64 / 0 \\
64 / 0 \\
8 \\
0 \\
0\end{array}$ \\
\hline
\end{tabular}

^Immunofluorescence test.

-Not tested.

independently with immediate recall of stories or drawings, serial learning, paired associated learning, and delayed recall. Memory was poor whatever the test condition, the performances ranging from 5 to $6 \mathrm{SD}$ below the normal values for age and education matched controls. Deficit was more distinct, however, for verbal than for visual memory. Performances had improved two months later but remained below the $2 \mathrm{SD}$ range except for paired associated learning which was in the normal range. Similar deficit was found in a third evaluation 14 months later.

\section{HISTOPATHOLOGY}

A biopsy specimen of the epitrochlear lymph node was taken one week after antibiotic treatment. Examination with haemalum-phloxinesaffron staining showed numerous granulomas, many of them being surrounded by a fibrohyalinised capsule containing lymphocytes. Granulomas were formed of epithelioid cells, some of them with central necrosis. They were surrounded by palisade-forming, predominantly epithelioid histiocytes with some lymphocytes. Some giant cells were present. No altered polymorphonuclear cells were found. A Warthin Starry silver impregnation did not show any gram-negative pleomorphic bacillus.

\section{LABORATORY INVESTIGATIONS}

CSF composition was initially normal, but later analyses showed pleocytosis and finally albumino-cytological dissociation (table). Serological studies were repeatedly negative for Epstein Barr virus, influenza, cytomegalovirus, brucella, rickettsia, tularemia, legionella, herpes, Lyme disease, poliomyelitis, HIV type 1, and syphilis. Levels of IgG antibodies against chlamydia as detected by immunofluorescence were elevated initially, before decreasing to a residual level three months later. Anti-toxoplasmosis IgG was also detected. IgM antibodies were present. CSF analysis for antibodies was negative. Blood and CSF cultures were normal.

\section{Discussion}

Our case satisfies the four diagnostic criteria of CSD: history of a close exposure to a cat with primary skin lesion; regional, mostly epitrochlear, adenopathy; positive cat scratch disease antigen intradermal reaction; and negative tests for other infections. Lymph node biopsy specimens showed non-caseating granuloma. The lack of polymorphonuclear cells in our case may have been related to the antibiotic treatment in the days preceding the biopsy. Many causal agents have been proposed such as herpes virus, chlamydia, or atypical mycobacteria. Recently a small gram negative pleomorphic bacillus has been isolated in the lymph node $^{8}$ and in inoculation site ${ }^{9}$ with silver impregnation stain and has been cultured ${ }^{10}$; this agent has been assigned to Rothia dentocariosa but the assignment of the bacillus to the disease remains debatable. ${ }^{11}$ As in many cases, we did not observe this bacillus. Positive serological tests for chlamydia and toxoplasma could be due to crossed antigenicity or nonspecific IgG synthesis associated with a concurrent infection. The presence of antibodies against Chlamydia psittaci could be explained by exposure to canaries a few months before encephalitis.

We are aware of only 59 cases of neurological manifestations in CSD, mostly presenting as encephalitis. ${ }^{51213}$ The course of encephalitis is usually stereotyped. Onset occurs two days to two months after the initial skin lesion, with headaches, malaise, anorexia, and slight fever. Neurological expression is usually limited to a generalised convulsion, followed by agitated coma for one to four days. As most patients recover without further illness, this encephalitis is considered benign. The course may be more severe, however, with a death rate as high as $8 \% .^{5}$ CSF examination, EEG, and CT scans are uninformative. The pathogenesis of neurological complications remains obscure. Direct bacterial invasion, vasculitis, ${ }^{14}$ and immunoallergic mechanisms ${ }^{12}$ have all been incriminated. The later theory is supported in our case both by the delayed high CSF protein content and by MRI pictures which show disseminated punctiform areas of increased signal in the white matter of the hemispheres. No other case of CSD encephalitis studied with MRI has been reported.

Our observation is unique because of the 
severe and lasting neurobehavioural changes after the acute episode of encephalitis. The reason for such a course is unknown as our patient did not differ from those with benign encephalopathy either on clinical, biological, or therapeutical grounds. Psychometric testing showed low IQ with altered spatial and constructive abilities. Memory deficit was initially global and then persisted as an anterograde deficit. The pattern of memory impairment might suggest an amygdalo-hippocampal involvement. Severity of cognitive impairment, however, makes it difficult to assess anatomo-clinical correlations of the amnestic syndrome.

We are grateful to Professor Aymard (Laboratoire de Bactériologie, Université Claude Bernard, Lyon) for her help in furnishing CSD antigen for the skin test, to Professor Tommasi (Laboratoire d'Anatomo-pathologie, Hopital Neurologique, Lyon) for his support, and to Professor Froment for MRI study.

1 Daniels WB, MaC Murray FG. Cat scratch-disease; non bacterial regional lymphadenitis: report of 60 cases. Ann bacterial regional lymphaden
Intern Med 1952;37:697-713.
2 Debré R, Lamy M, Jammet ML, Costil L, Mozziconacci P. a maladie des griffes de cat. Sem Hop Paris La maladie des

3 Mollaret P, Reilly J, Bastin R, Tournier P. Adénopathie régionale subaigué spontanément curable avec IDR et lésions histologiques particulières. Bull Mem Soc Med Hop Paris 1950;66:424-49.

4 Carithers HA. Cat-scratch disease. An overview based on a study of 1200 patients. Am J Dis Child 1985;139:1124-33.

5 Bruyn GW. Cat-scratch disease. In: Winken PJ, Bruyn GW, eds. Handbook of neurology. Amsterdam, North Holland: 1978:459-74.

6 Lyon LW. Neurological manifestations of cat-scratch disease. Arch Neurol 1971;25:23-7.

7 Signoret JL, Whiteley A. Memory battery scale. Intern Neuropsych Soc Bull 1979;9:2-26.

8 Wear DJ, Margileth AM, Hadfield TL, Fischer GW Schlagel CJ, King FM. Cat-scratch disease: a bacerial infection. Science 1983;221:1403-4.

9 Margileth AW, Wear DJ, Hadfield TL, Schlagel CJ, Spigel GT, Muhlbauer JE. Cat-scratch disease: bacterial in skin at the primary inoculation site. $J A M A$ 1984;252:928-31.

10 English CK, Wear DJ, Margileth AM, Lissner CR, Walsh GP. Cat scratch disease: isolation and culture of the bacterial agent? JAMA 1988;259:1347-52.

11 Hadfield TL, Wear DJ, Margileth AM, English CK. Is rothia dentocariosa the cause of cat scratch disease? Lancet 1985;28:720-1.

12 Bonneau D, Desbordes JM, Poncin E, Becq-Giraudon C. Manifestations encéphalitiques au cours de la maladie des griffes du chat. Sem Hop Paris 1985;17:1165-7.

13 Lewis DW, Tucker S. Central nervous system involvement in cat scratch disease. Pediatrics 1986;77(5):714-21.

14 Selby G, Walker GL. Cerebral arteritis in cat-scratch disease. Neurology 1979;29:1413-8.
. 